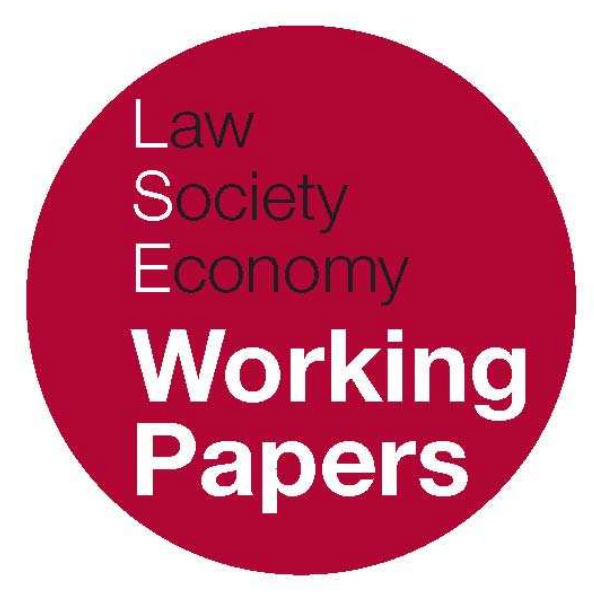

\title{
Constitutional Exceptionalism and the Common Law
}

\author{
Thomas Poole
}

LSE Law, Society and Economy Working Papers 14/2008 London School of Economics and Political Science

Law Department

This paper can be downloaded without charge from LSE Law, Society and Economy Working Papers at: www.lse.ac.uk/collections/law/wps/wps.htm and the Social Sciences Research Network electronic library at: http://ssrn.com/abstract=1269271.

(C) Thomas Poole. Users may download and/or print one copy to facilitate their private study or for non-commercial research. Users may not engage in further distribution of this material or use it for any profit-making activities or any other form of commercial gain. 


\title{
Constitutional Exceptionalism and the Common Law
}

\author{
Thomas Poole*
}

\begin{abstract}
This paper examines the notion of exceptionalism, currently pervasive within constitutional discourse. The term 'exceptionalist' is used in this context to indicate a measure which deviates from normal constitutional standards and is, by virtue of that deviation, seen as inappropriate or regrettable. The paper avoids a direct focus on the debate about terrorism, concentrating instead on more conceptual matters - and particularly the 'fit' between this discourse and the 'common law constitution'. Part I turns to John Locke and uses his theory of the prerogative as a means of highlighting the difficulty of determining what counts as 'exceptional' in this, our 'age of statutes'. Part II raises concerns about the common law constitutionalists' theory of emergency powers, articulated most skilfully by Dyzenhaus, and argues that this theory rests on a mistaken understanding of the nature of common law. Part III addresses the issue of extra-constitutionality and common law more generally, taking as its focus the 'extra-legal measures model' of emergencies advocated by Gross and Tushnet. On the back of this critical analysis, the paper ends by raising questions about the 'public role' of constitutional scholars: have we been too ready, it asks, to deny the complexity of our discipline in order to make political points?
\end{abstract}

\section{INTRODUCTION}

The language of exceptionalism currently pervades constitutional discourse. Casting around for a vocabulary with which to analyse and criticize political and legal developments since the September 11th attacks, commentators have latched onto the norm/exception diptych as a means of expressing the 'new constitutional

\footnotetext{
* Law Department, London School of Economics. I would like to thank Mark Aronson, Carol Harlow, David Kershaw and Martin Loughlin for their comments on an earlier draft. The paper was first given, in abbreviated form, at a seminar at the European University Institute on 4 March 2008, and I am grateful to Wojciech Sadurski inviting me to speak.
} 
reality'. While the language of exceptionalism is sometimes used to justify or defend calls for 'special' executive powers, it is more often used as a basis for criticism. The notion of exceptionalism, that is to say, lends itself to two main arguments: (i) that recent measures relating largely but not exclusively to the 'war on terrorism' amount to a fundamental deviation from normal constitutional and legal standards; (ii) that this deviation from normal standards, even if we should accept it as appropriate in the current climate, is necessarily a bad thing.

Debate around the apparently primordial norm/exception, constitutional/anti-constitutional binaries is spawning almost a new sub-branch of constitutional theory, behind which lurks the darkly alluring figure of Carl Schmitt. Schmitt's relentless focus on the exception as the residue of pre- and supraconstitutional sovereign authority has provided the theoretical impetus behind this new discourse. ${ }^{1}$ Giorgio Agamben's influential work on the state of exception and the figure of homo sacer, the liminal figure of the man who can be killed but not murdered that he takes as emblematic of modern legal orders, begins as a kind of gloss on the work of the German writer. ${ }^{2}$ A number of US-based constitutional lawyers - notably Gross and Tushnet - have gone back to Schmitt in order to ground a proposal for an extra-constitutional approach to dealing with situations of crisis. ${ }^{3}$ Even Dworkinian liberals are not immune from Schmitt's reach. Dyzenhaus, in his recent work on legality in situations of emergency, defines his own model of a 'beefed-up' common law rule of law as a response to the Schmittian challenge. ${ }^{4}$

I reflect on this discourse in this paper. The analysis brackets claims about the value, instrumental or otherwise, of recent anti-terrorism measures in order to concentrate on more conceptual arguments and assumptions. Part I uses Locke's argument concerning prerogative power as a platform from which to assess the difficulties associated with determining what counts as 'exceptional' power in our 'age of statutes'. Part II looks critically at the common law constitutionalists' theory of emergency powers, propounded most compelling by Dyzenhaus, according to which what fails to fit with fundamental principles associated with the rule of law may be counted as exceptional and as such considered illegitimate. Part III addresses the issue of extra-constitutionality more generally, taking as its focus the 'extra-legal measures model' of emergency power advocated by Gross and Tushnet.

${ }^{1}$ C. Schmitt, Political Theology (Chicago: University of Chicago Press, ed. G. Schwab, 2006).

2 G. Agamben, Homo Sacer: Sovereign Power and Bare Life (Stanford: Stanford University Press, 1998); G. Agamben, State of Exception (Chicago: University of Chicago Press, 2005).

3 O. Gross, 'The Normless and Exceptionless Exception: Carl Schmitt's Theory of Emergency Powers and the "Norm-Exception" Dichotomy' (1999) 21 Cardozo Law Review 1825; M. Tushnet, 'Defending Korematsu? Reflections on Civil Liberties in Wartime' (2003) Wisconsin Law Review 273.

${ }^{4}$ D. Dyzenhaus, The Constitution of Law: Legality in a Time of Emergency (Cambrdige: Cambridge University Press, 2006). Dyzenhaus explored Schmitt's constitutional theory in Legality and Legitimacy: Carl Schmitt, Hans Kelsen and Hermann Heller in Weimar (Oxford: Clarendon Press, 1997). 


\section{PART I: HUNTING THE EXCEPTION}

\section{Locke AND The Prerogative}

I begin with John Locke, one of the few liberal theorists to give serious thought to the idea of constitutional exceptionality. His analysis of 'the exception' concentrates on the prerogative, since that was the source of exceptional or emergency power in his day. Locke does not doubt the need for a prerogative power to be vested in the executive. 'Many things there are, which the law can by no means provide for; and those must necessarily be left to the discretion of him that has the executive power in his hands' (\$. 159). Since 'the end of government being the preservation of all', necessity calls for discretionary power - a 'reservoir of authority,, 5 in John Dunn's phrase - capable of augmenting or supplanting existing rules (and rule-based authority structures) in cases of need. As it is impossible 'to foresee, and so by laws provide for, all accidents and necessities that may concern the public ... therefore there is a latitude left to the executive power, to do many things of choice which the laws do not prescribe' (\$. 160). On occasion - where the laws are silent, or where to follow the letter of the law would lead to injustice, or where the good of the people requires it - it is entirely legitimate, Locke argues, for the executive to go beyond or even against the existing law. ${ }^{6}$

There is much that could be said about Locke's theory of the prerogative; but I want to focus on the following points. In Locke's analysis, the exercise of normal and exceptional powers takes distinct forms. Law-making powers are exercised in the normal course of events by a representative legislature and the common law courts. Exceptional actions are taken under the auspices of the prerogative. (I avoid the term 'law' to describe such acts, since Locke is clear that the prerogative is a power extra et contra legem: outside the constitution of 'settled, standing, law'.) Not only is the formal source of power different; so too is the basis upon which the exercise of such power is legitimated. Normal law is justified in the first instance by its adherence to the normal law-making process, and ultimately by the freely willed consent of the people to that process. The legislative power, Locke says, is 'the supreme power of the common-wealth', sacred and inviolable; no 'edict of any body else... have the force and obligation of a law, which has not its sanction from that legislative which the public has chosen and appointed' (\$. 143)..$^{7}$ Prerogative power - defined by Locke as 'nothing but the power of doing public

\footnotetext{
5 J. Dunn, The Political Thought of John Locke (Cambridge: Cambridge University Press, 1969) 149.

${ }^{6}$ Cf Hamilton's argument in The Federalist, No. 70: 'Energy in the Executive is a leading character in the definition of good government. It is essential to the protection of the community against attacks ... to the security of liberty against the enterprise and assaults of ambition, of faction, and of anarchy.'

${ }^{7}$ Cf Articles 1 \& 2 of the Bill of Rights 1689, which declare that the 'pretended power of suspending of laws, or the execution of laws, by regal authority, without consent of parliament, is illegal', and the same applies to the 'pretended power of dispensing with laws'. For analysis see R.C. van Caenegem, $A n$ Historical Introduction to Western Constitutional Law (New York: Cambridge University Press, 1995) 115-7.
} 
good without a rule' - is justified by the dictates of necessity (in its various guises): 'it is fit that the laws themselves should in some cases give way to the executive power, or rather to this fundamental law of nature and government, vi\%. That as much as may be, all the members of the society are to be preserved' ( $\$$. 159).

Locke thus develops a framework that embraces two opposing sites or spheres of authority, the legal and the prudential. These two spheres relate to two distinct types of power. One source operates in a structured way, according to established institutional and procedural norms, and results in the passing and application of presumptively legitimate general laws. The other is unstructured and at least potentially unconstrained - hence threatening - and is justified (or not) by the dictates of necessity. (Specifically, an exercise of the prerogative is justified if the people accept that it meets the exigencies of the situation in question. But, as Locke pointed out, the people tend to be credulous in this context.) ${ }^{8}$ Note the series of juxtapositions or oppositions at work here: law versus prerogative; rulebound structure versus formless power, the political order grounded in persuasion versus the realm of violence or pure power'; the solid and presumptively legitimate versus the potentially menacing; rational versus irrational. ${ }^{10}$

There is a deeper texture to this framework. It is clear from Locke that prerogative power while necessary is, with its potential to open up the realm of force, also to be feared. But it is equally the case that the prerogative also offers a 'revolutionary' moment in which it is possible for people to think through the existing structures of authority anew. This is unsurprising. Locke, as well as being a founding father of liberal constitutionalism, was also one of the first theorists of rebellion. ${ }^{11}$ And it is precisely within the Lockean version of the state of exception - that is, when prerogative power is claimed - that rule-bound legality shatters to reveal the 'authentic' political moment, when people and sovereign stand face to face. So much is clear from Locke's answer to the question: 'But who shall be judge when this [prerogative] power is made a right use of?' The answer he gives is initially disquieting: 'there can be no judge on earth'. This being so, the people 'have no other remedy in this, as in all other cases where they have no judge on earth, but to appeal to heaven' (\$. 168). This is Lockean code for an appeal to heaven by seeking battle. 'It is trial by battle by which the judgement of God is sought; to appeal to heaven is to take to war.' 12 A bad exercise of the prerogative puts people in a state of nature, not in respect of each other, but with the old government or king. The king is now 'justly to be esteemed the common enemy

\footnotetext{
8 J. Locke, Second Treatise on Civil Government (Buffalo, N.Y.: Prometheus Books, 1986) S 161: 'for the people are very seldom or never scrupulous or nice in the point; they are far from examining prerogative, whilst it is in any tolerable degree employed for the use it was meant, that is, for the good of the people, and not manifestly against it'.

${ }^{9}$ H. Arendt, On Revolution (London: Penguin, 1990), Introduction.

10 P. Pasquino, 'Locke on King's Prerogative' (1998) 26 Political Theory 198.

11 See, e.g., R. Ashcraft, Revolutionary Politics and Locke's Two Treatises of Government (Princeton, N.J.: Princeton University Press, 1986).

12 R. Harrison, Hobbes, Locke, and Confusion's Masterpiece (Cambridge: Cambridge University Press, 2003) 217-8.
} 
and pest of mankind; and is to be treated accordingly' (\$. 230). Government, that is to say, is dissolved (in the judgement of the people) on the bad exercise of the prerogative. Locke's constitutional universe, if we may call it that, allowed for (or acknowledged the existence of) a space almost outside the normal constitutional framework which, as well as being politically necessary, also opened up the possibility of a quasi-state of nature situation in which existing constitutional forms might be 're-negotiated'.

\section{Prerogative in an Age of Statutes}

But to what extent, in this age of statutes, ${ }^{13}$ do we still move in Locke's shadow? Many ideas - particularly constitutional ones - developed in the fulcrum of seventeenth century politics do continue to have purchase in our own time. ${ }^{14}$ But one substantial difference between Locke's theory of emergency powers (if we may call it that) and the current situation relates to constitutional form. In our era, more often than not, emergency powers are not straightforward exercises of prerogative (or similar executive) powers ${ }^{15}$ but are statutory in origin. This is certainly the case in contemporary Britain, where the main post-September 11th anti-terrorism powers, justified on the basis of the need to meet a crisis situation, are all statute-based. ${ }^{16}$ The emergency regimes that operated in both World Wars were statutory in origin, ${ }^{17}$ as were the successive exceptional measures designed to deal with various 'emergency' situations in Northern Ireland. ${ }^{18}$ Commentators have noticed similar patterns elsewhere. Scheppele, for instance, has charted the worldwide spate of 'copy-cat' legislative developments since 9/11. ${ }^{19}$ In this respect as in so many others, the United States has led the way, with the PATRIOT Act

\footnotetext{
${ }^{13}$ G. Calabresi, A Common Law for the Age of Statutes (Cambridge, Mass.: Harvard University Press, 1982).

${ }^{14}$ See, e.g., D. Zaret, Origins of Democratic Culture (Princeton, N.J.: Princeton University Press, 2000). For a recent attempt to map the English/British constitution in these terms see A. Tomkins, Our Republican Constitution (Oxford: Hart, 2005).

15 There is some disagreement over the definition of the prerogative. In his Commentaries, Sir William Blackstone offered a relatively narrow definition - prerogative power is in its nature singular and eccentrical [in] that it can only be applied to those rights and capacities which the king enjoys alone ... and not to those which he enjoys in common with any of his subjects' (Commentaries on the Laws of England Oxford: Clarendon Press [1765], i., 232). Dicey gave the prerogative a broader meaning - the prerogative, he said, consists of the 'residue of discretionary or arbitrary authority which at any given time is legally left in the hands of the Crown' (Introduction to the Study of the Law and the Constitution [1885] (MacMillan; St. Martin's P, 10th ed, 1959) 424).

16 Anti-Terrorism, Crime and Security Act 2001; Civil Contingencies Act 2004; Prevention of Terrorism Act 2005; Terrorism Act 2006; Counter-Terrorism Bill 2008.

${ }^{17}$ Defence of the Realm Act 1914; Emergency Powers (Defence) Act 1939. The infamous decision of the House of Lords in Liversidge v Anderson [1942] AC 206 involved a challenge to the exercise of detention powers under Regulation 18B of the Defence (General) Regulations 1938.

18 Prevention of Terrorism Act 1974 (amended 1976, 1984 and 1989). Those measures were consolidated by another statute: the Terrorism Act 2000. See C. Walker, The Prevention of Terrorism in British Law (Manchester: Manchester University Press, 2nd ed, 1992); C. Gearty, Can Human Rights Survive? (Cambrige: Cambridge University Press, 2006), ch. 4. Those measures were consolidated by another statute: the Terrorism Act 2000.

${ }^{19}$ K. Scheppele, 'Other People's PATRIOT Acts: Europe's Responses to September 11' (2004) 50 Loyola Law Review 89; K. Roach, 'Sources and Trends in Post 9/11 Anti-terrorism Laws' in B.J. Goold and L. Lazarus (eds), Security and Human Rights (Oxford: Hart, 2007).
} 
and subsequent legislation. ${ }^{20}$ What we have seen, then, is a general (although by no means complete ${ }^{21}$ ) move away from the direct resort to prerogative or executive powers to the use of statutes which create substantial new powers with which to deal with putative crises.

The movement from prerogative to statute in crisis law-making is an important and under-theorised trend. As we have seen, Locke's theory of emergency powers rested on a clear-cut distinction between prerogative and 'normal' legislation. But this formal distinction no longer operates. Instead, more often than not, extraordinary grants of power - justified as ever on grounds of necessity - wear the same ('normal', constitutional) clothes. Both 'normal' and 'exceptional' powers are products of the same legislative process, as a result of which the traditional formal separation between norm and exception no longer pertains. The strongest claim that might now be made concerning law-making form might pick up on the curtailed, even bowdlerised, manner in which much emergency legislation is passed. This was certainly a feature of the Anti-Terrorism, Crime and Security Act 2001 in the UK and the US PATRIOT Act, both passed shortly after the September $11^{\text {th }}$ attacks. ${ }^{22}$ There are two difficulties with this argument. First, not all 'crisis' legislation is passed in this way - it is not true, for instance, in relation to the anti-terrorism statutes passed in the UK after 2001. Second, other types of legislation are sometimes passed in an equally curtailed manner - the Dangerous Dogs Act 1991 is a classic British example.

This trend towards emergency legislation has an institutional corollary. In Locke's account, it was clear who exercised what power when. Normal laws were passed by the legislature, usually at the request of the executive. The prerogative, originally the paradigmatic kingly power, was vested in the executive, whether royal or not. The fact that, as happened historically in England and elsewhere, prerogative powers which were once emanations of royal authority ended up being exercisable by a non-royal authority is not immediately significant. What is significant is that the symbiotic relationship that was established between legislature and executive, Parliament and government, helped to undermine the clear-cut institutional distinction prevalent in Locke's theory. What was once (an expression of) distinctively royal power is now one that exists in a murky 'greyzone' between the authority of the legislature and the power of the executive.

This development also has a theoretical dimension connected with the rise of democracy as the central legitimating idea of most modern political communities. ${ }^{23}$

\footnotetext{
${ }^{20}$ United and Strengthening America by Providing Tools for Intercepting and Obstructing Terrorism Act 2001 (amended March 2006); Homeland Security Act 2002; Support Anti-Terrorism by Fostering Effective Technologies Act 2002; Military Commissions Act 2006. The Authorization of Military Force (September 18, 2001) is a Congressional Joint Resolution.

21 See, e.g., Executive Order 13224, 66 Fed. Reg. 49,079 (Sept 23, 2001). See also J.P. Pfiffner, 'The Contemporary Presidency Constraining Executive Power: George W. Bush and the Constitution’ (2008) 38 Presidential Studies Quarterly 123.

22 See, e.g., A. Tomkins, 'Legislating against Terror' [2002] PL 205; H. Fenwick, 'A Proportionate Response to 11 September?’ (2002) 65 MLR 724.

23 See, e.g., J. Dunn, Setting the People Free: The Story of Democracy (London: Atlantic, 2005).
} 
Democracy has displaced both tradition ( $f$ the common law) and (kingly) authority ( $c f$ the prerogative) as legitimate sources of authority. We see this principle at work in the history of the prerogative in England, both in the erosion of prerogative as a matter of political practice and in relation to the legal rules that circumscribe its exercise. (Consider, for instance, the rule that once Parliament has legislated on a matter that was once the subject of prerogative power, that power is no longer extant. ${ }^{24}$ ) In constitutional terms, we may see this development in terms of the gradual swallowing by Parliament of prerogative (i.e. extra-Parliamentary) powers. ${ }^{25}$ As Lord Browne-Wilkinson observed in the Fire Brigades Union case, 'The constitutional history of this country is the history of the prerogative powers of the Crown being made subject to the overriding powers of the democratically elected legislature as the sovereign body. ${ }^{26}$ The presumption now is that, even in those areas where prerogative powers still formally hold sway, Parliamentary approval or consent should be sought. This was evidenced when Tony Blair PM sought (and obtained) Parliament's approval for the UK's participation in the ongoing war in Iraq, although such approval was not legally necessary. ${ }^{27}$

We should be wary of seeing this process in terms of a linear story of the evolution of democratic constitutionalism, although it is certainly in part about that. Two relevant phenomena pull against this comfortable (and comforting?) Whiggish narrative. Co-existent with the rise of democracy in many countries has been the gradual domination by the executive of the legislature. This has certainly been the general pattern in the UK. ${ }^{28}$ The power of the executive has tended to increase during the democratic era, both in absolute terms and vis-à-vis legislatures. ${ }^{29}$ In addition, the trend has been for legislation to grant ever wider discretionary power to the executive..$^{30}$ This process is a direct result of democratic imperatives. The call for broad, discretionary powers relates to the growth first of the administrative state in the late $19^{\text {th }}$ century and then the Welfare State in the $20^{\text {th }}$ - and (who knows?) the 'security state' in the $21^{\text {st. }} .31$ In other words, the same principle that worked to clip the wings of the prerogative has also contrived to

\footnotetext{
24 Attorney-General v De Keyser's Royal Hotel [1920] AC 508, where the House of Lords rejected the government's reliance on the prerogative in relation to the requisition of property for military purposes in the First World War. The relevant powers had been superseded by the Defence of the Realm Act 1914.

25 See, e.g., P. Craig, 'Prerogative, Precedent and Power' in C. Forsyth and I. Hare (eds), The Golden Metwand and the Crooked Cord (Oxford: Clarendon Press, 1997).

${ }^{26} \mathrm{R} v \mathrm{v}$ Secretary of State for the Home Department, exp Fire Brigades Union [1995] 2 AC 513, 552.

${ }^{27}$ See, e.g., House of Commons Public Administration Select Committee, 'Taming the Prerogative: Strengthening Ministerial Accountability to Parliament' (4 March 2004).

${ }^{28}$ Lord Hewart, The New Despotism (London: Benn, 1929); C.K. Allen, Law and Orders (London: Stevens, 1945); Lord Hailsham, The Dilemma of Democracy: Diagnosis and Prescription (London: 1978).

${ }^{29}$ See, e.g., A. Tomkins, Public Law (Oxford: Oxford University Press, 2003) 95: 'In practice the legislative agenda of Parliament has for some time fallen under the control of the government of the day.'

${ }^{30}$ For instance, the rise of so-called 'Henry VIII clauses' (provisions that allow government ministers to amend and repeal statutory provisions by statutory instrument) in the UK: see, e.g., N. Barber and A. Young, 'The rise of prospective Henry VIII clauses and their implications for sovereignty' [2003] PL 112. It should be noted, however, that the British Parliament is not always supine in relation to such developments: see, e.g., Tomkins, n 14 above, 126-30.

${ }^{31}$ See, e.g., I. Loader and N. Walker, Civilizing Security (Cambridge: Cambridge University Press, 2007); J. Habermas, Between Facts and Norms (Cambridge: Polity Press, 1996) 433.
} 
produce Hayek's (and Dicey's) nightmare of vast tracts of discretionary powers being vested in the executive officers of the state. ${ }^{32}$

We can now address the question posed at the outset of the section: what relevance does Locke's framework now have? Locke imagined a series of binaries that pivoted on a formal distinction between different sources of power, law and prerogative. But that formal dichotomy no longer prevails. Prerogative (or executive) power does still exist but, no longer being exercisable by kings, takes a different colouring. It is also problematic because of its dissonance with the overriding importance of the democratic principle. Within the UK and elsewhere, ${ }^{33}$ the general trend has been to rely less on the prerogative and to subject its operation to more substantial legal control. ${ }^{34}$ The democratic impulse has also driven the practice of avoiding the use of prerogative power in one of the ways envisaged by Locke: as the primary means of dealing with situations of crisis or emergency. Although they may be justified in a different way from 'ordinary' legislation, emergency powers tend now to have their source more often than not in the normal statutory process.

Some may be tempted to see these developments in terms of a simple story of constitutionalism, even a logical unfolding of the constitutionalist persuasion manifest in Locke's political writings. In this vein, the gradual eclipse of the prerogative might be seen as a denial or sublimation of the irrational and violent element within politics and the rise of a mature, Rawlsian framework of open, public reason..$^{35}$ But we should pause before accepting this linear account. The (partial) demise of the prerogative entails that the previously self-evident formal distinction between normal and emergency powers no longer prevails. The system that currently operates helps to submerge this problem, since 'normal' and 'emergency' powers now wear similar constitutional (statutory) clothes. This leaves us without a formally obvious, cut-and-dried distinction between what we should treat as normal and what exceptional. This situation is problematic from the Lockean standpoint. Locke's prerogative was a special power that carried with it special dangers. To be unable to tell clearly when a special power has been triggered deprives the people of its moment (Locke would say right) to reflect and challenge the suitability of both the special power claimed and the authority that

32 Actually, from the viewpoint of a modern-day Hayek or Dicey, the situation is probably even worse as these powers are increasingly not vested in public officials but in private hands and often not entrusted to officers of the state but to decision-makers at the supranational or international level: see, e.g., G. Anderson, Constitutional Rights after Globalization (Oxford: Hart, 2005).

${ }^{33}$ For comparative analysis see P. Craig and A. Tomkins (eds), The Executive and Public Law: Power and Accountability in Comparative Perspective (Oxford: Oxford University Press, 2006).

${ }^{34}$ Council of Civil Service Unions v Minister for the Civil Service [1985] AC 374 - where the House of Lords held that in principle the source of power was not relevant to the question of legal supervision, thus removing the traditional principle whereby the exercise (but not the existence) of prerogative power was immune from judicial review. $R$ (Bancoult) v Secretary of State for Foreign and Commonwealth Affairs [2007] EWCA Civ 498 - where the Court of Appeal quashed as an abuse of power certain provisions in two prerogative Orders in Council made by the Queen on 10 June 2004 on the advice of the Foreign Secretary preventing the repatriation of the Chagos Islanders.

35 J. Rawls, Political Liberalism (New York: Columbia University Press, 1993). 
lays claim to it. This situation of uncertainty is particularly pronounced where, as commentators now observe, many of the same justifications for emergency powers - fear, (in)security, risk - are deployed with increasing frequency to defend other, non-emergency laws. ${ }^{36}$ The problem is further compounded if we expand Locke's empirical observations concerning the workings of crisis-related powers. Experience tells us that it is not just the people that are credulous when faced with executive claims for special powers. Politicians - and, for that matter, judges too tend more often than not to fall under the same spell. ${ }^{37}$ This situation is compounded by the trend towards curtailing the independence of parliamentarians by the force of party structures and for the legislature to be dominated by the executive. ${ }^{38}$

We might suggest, then, a darker gloss to the constitutionalist thesis (conceit?). It is inappropriate to talk as though the constitutional order itself were involved in a conspiracy to defraud the people it is designed to serve. But might it not be the case that corralling the prerogative within a constitutionalist framework has also resulted in an attempt to foreclose the 'authentic' moment for which Locke simultaneously feared and longed for, in which a claim for special powers triggered a moment in which conceptually at least (and sometimes in political practice) ruler and ruled stood face to face, a moment that offered the possibility of reordering the operative structures of authority? Seen from this perspective, developments driven by 'good' or 'normalising' democratic and constitutionalist principles have unwittingly produced a situation characterised by a double deceit. The deceit of wrapping claims for special powers in normal legislative clothes. And the deceit of apparently forestalling even the conceptual possibility of entering the quasi-state of nature moment in which political rejuvenation is possible.

\section{PART II: EXCEPTIONALISM AND THE COMMON LAW}

A different way of approaching the norm/exception distinction prevalent in some common law countries argues that the common law is the repository of normal legal and constitutional standards and that a decision to act outside those

\footnotetext{
36 See, e.g., F. Furedi, Politics of Fear (London: Continuum, 2005); B. Buzan, O. Waever and J. de Wilde, Security: A New Framework for Analysis (Boulder, CO: Lynne Rienner, Publishers, 1998); Loader and Walker, n 27 above.

${ }^{37}$ B. Ackerman, Before the Next Attack: Preserving Civil Liberties in an Age of Terrorism (New Haven: Yale University Press, 2006) 1-3: Ackerman argues that the traditional recourses of the constitutional lawyer democracy and the courts - are inadequate, even problematic in contemporary crisis situations. Democracy is the 'root of the problem', since competitive elections tempt politicians 'to exploit the spreading panic to partisan advantage'. And courts 'haven't protected us in the past' in analogous situations, 'and they will do worse in the future.' Although it must be said that recent experience does not all point in this direction: see T. Poole, 'Conditions of Uncertainty in "Times of Crisis"” [2007] PL 234. ${ }^{38}$ See, e.g., P. Cowley and M. Stuart, 'Parliament: More Bleak House than Great Expectations' (2004) 57 Parliamentary Affairs 301.
} 
standards equates to an 'exceptional' situation. Instead of locating the distinction between normal and exceptional in the legislative/political sphere, then, this approach locates it on the juridical plane. It is perhaps worth noting that this is not the path Locke chose to follow. Locke's neglect of the common law ${ }^{39}$ no doubt relates to the milieu in which he operated, since common law constitutionalism was a phenomenon of the earlier rather than the later $17^{\text {th }}$ century. And it is to these early $17^{\text {th }}$ century theorists of the common law - and, above all, Sir Edward Coke $^{40}$ - to whom contemporary common law constitutionalists now turn. Coke and others developed a theory of ancient constitutionalism, at the heart of which was the idea that the common law embodied an ancient constitution stretching from 'time immemorial' combined with the belief that the language and values of the common law properly possessed hegemonic status within political debate. ${ }^{41}$ The theory of ancient constitutionalism was highly influential in the first decades of the $17^{\text {th }}$ century in particular, and not just within legal circles. ${ }^{42}$ But its influence had largely dwindled by the time of the English Civil War in the 1640s.

Common law constitutionalism has recently undergone a remarkable revival. ${ }^{43}$ This development has coincided with both the growth of human rights discourse ${ }^{44}$ and the continued juridification of the public sphere. ${ }^{45}$ The work of T.R.S. Allan has helped drive this renaissance. Allan argues that the common law provides a 'scheme of justice that embodie[s] the traditions of the community'46 and has become the principal site of accrued wisdom within the polity, providing the 'common values' which reflects and embodies the enduring experience of the community. 'It is in this fundamental sense that Britain has a common law constitution: the ideas and values of which the rule of law consists are reflected and embedded in the ordinary common law. ${ }^{47}$ The connection between the common law and the

${ }^{39}$ J. Waldron, The Dignity of Legislation (Cambridge: Cambridge University Press, 1999).

40 On Coke see, e.g., C. Gray, 'Reason, Authority, and Imagination: the Jurisprudence of Sir Edward Coke' in P. Zagorin (ed.), Culture and Politics from Puritanism to the Enlightenment (London: University of California Press, 1980); H. J. Berman, 'The Origins of Historical Jurisprudence: Coke, Selden, Hale' (1994) 103 Yale LJ 1651; J. U. Lewis, 'Sir Edward Coke (1552-1633): His Theory of “Artificial Reason” as a Context for Modern Basic Legal Theory' (1968) 84 LQR 330.

${ }^{41}$ J.G.A. Pocock, The Ancient Constitution and the Feudal Law (Cambridge: Cambridge University Press, 2nd ed, 1987)

${ }^{42}$ G. Burgess, The Politics of the Ancient Constitution (Houndsmills, Basingstoke, Hampshire: Macmillan 1992).

43 T. Poole, 'Back to the Future? Unearthing the Theory of Common Law Constitutionalism' (2003) 23 OJLS 435.

${ }^{44}$ See, e.g., M. Loughlin, 'Rights, Democracy, and Law' in T. Campbell, K.D. Ewing and A. Tomkins (eds), Sceptical Essays on Human Rights (Oxford: Oxford University Press, 2001).

${ }^{45} \mathrm{~J}$. Habermas, The Theory of Communicative Action, Vol. 2 (Cambridge: Polity Press, 1987) 359: juridification is the 'proliferation of law' or 'the tendency towards an increase in formal (or positive, written) law'; A. Stone Sweet, 'Judicialization and the Construction of Governance' in M. Shapiro and A. Stone Sweet, On Law, Politics and Judicialization (Oxford: Oxford University Press, 2002).

46 T.R.S. Allan, Constitutional Justice: A Liberal Theory of the Rule of Law (Oxford: Oxford University Press, 2001) 19. Note that common law constitutionalism is not simply a UK-based phenomenon: see, e.g., M. Walters, 'The Common Law Constitution and Legal Cosmopolitanism' in D. Dyzenhaus (ed.), The Unity of Public Law (Oxford: Hart, 2004); S. Gageler, 'The Underpinnings of Judicial Review of Administrative Action: Constitution or Common Law?' (2000) 28 Federal Law Review 303.

47 T.R.S. Allan, Law, Liberty, and Justice: The Legal Foundations of British Constitutionalism (Oxford: Clarendon Press, 1993) 4. 
polity's basic values means that the former performs a foundational role: it actually constitutes the basic order of political society. ${ }^{48}$ As a reflection or embodiment of the common law's repository of political wisdom, the rule of law is understood in a 'thick' or value-laden sense and takes centre stage. ${ }^{49}$

David Dyzenhaus has produced the most thorough articulation of the common law constitutionalists' position on emergency powers. Drawing on Allan's account of a value-laden rule of law deriving principally from the common law and articulated in the courts, Dyzenhaus argues that the common law is capable of providing a framework from which to assess governmental action in situations of emergency. Not only can the rule of law, he argues, perform the relatively straightforward task of identifying and countering so-called 'legal black holes' - that is, situations where the writ of law (however conceptualised) does not run. ${ }^{50}$ But, when understood as a strong principle of legality nourished by deeprooted common law values, it can also detect and attack what Dyzenhaus calls 'grey holes' - the more common, and potentially more insidious, situation where there exists the appearance of legality but substantive illegality or unfairness. ${ }^{51}$ The 'rule-of-law project' that Dyzenhaus advances is based on 'a rather bare common law' conception of legality, he says, 'enriched by the way in which such a conception has to be updated, most recently because of the central place taken by an international and domestic discourse of human rights in our thinking about law.' 52

The common law constitutionalist theory of emergency powers does have its attractions. By focussing on substance rather than form, it avoids the identification problems associated with the move from prerogative to statute noted in the previous section. Common law constitutionalists appear not overly concerned with constitutional form. ${ }^{53}$ They present a theory which seems, on its face, to care

48 T.R.S. Allan, 'Common Law Constitution and Freedom of Speech' in J. Beatson and Y. Cripps (eds), Freedom of Expression and Freedom of Information (Oxford: Oxford University Press, 2000).

${ }^{49}$ T.R.S. Allan, 'The Rule of Law as the Rule of Reason: Consent and Constitutionalism' (1999) 115 LQR 221. The 'thick', common law based conception of the rule of law defended by Allan has received some support from senior British judges. The senior Law Lord, Lord Bingham, argued in a widely publicized lecture that the rule of law contained eight core principles: the law must be accessible and intelligible; disputes must be resolved by application of the law rather than exercise of discretion; the law must apply equally to all; it must protect fundamental human rights; disputes should be resolved without prohibitive cost or inordinate delay; public officials must use power reasonably and not exceed their powers; the system for resolving differences must be fair; a state must comply with its international law obligations. See L Bingham, 'The Rule of Law' (16 Nov 2006) http://www.cpl.law.cam.ac.uk/past_activities/ the_rt_hon_lord_bingham_the_rule_of_law.php.

${ }^{50}$ See also L Steyn, 'Guantanamo Bay: The Legal Black Hole' (2004) 53 ICLQ 1.

${ }^{51}$ Dyzenhaus, The Constitution of Law, $\mathrm{n} 4$ above.

52 ibid, 13.

53 Consider, for instance, Allan's argument against the notion of judicial deference, which he regards as nothing more than 'non-justiciability dressed in pastel colours.' Deference, he argues, is either an empty or a pernicious doctrine. It is empty if it 'purports to implement a separation of powers between the courts and other branches of government', since such a separation is secured by 'the proper application of legal principles defining he scope of individual rights'. It is pernicious if 'it permits the abdication of judicial responsibility in favour of reliance on the good faith or good sense or special expertise of public officials, whose judgments about the implications of rights in specific cases may well be wrong.' Considerations not directly related to the right in question - for instance, those that relate to 'characteristics of the decision-maker or its procedures' - are classified as 'external considerations' 
only about whether an exercise of power fits within a particular normative framework. Moreover, the 'argument from history' which they deploy, while yet another example of lawyers' capacity for anachronistic and self-aggrandising mythmaking, may provide some useful cover when the political flak starts flying in this most highly contested of areas. ${ }^{54}$ More importantly perhaps, Dyzenhaus must be right in suggesting that the rule of law is virtually redundant (not to say meaningless) unless it can distinguish to some degree at least between situations of 'true' legality and cases where only a façade of legality applies to cover expressions of brute power.

That said, I have reservations about the common law thesis. The theory relies on a reasonably well defined - 'hard-edged' - notion of the common law as repository of substantive moral/political values. It is revealing, then, that Dyzenhaus' account starts to unravel at precisely the point where it should be most strong. For when it comes to specifying with a requisite degree of precision what those 'hard-edged' values which derive from the common law and give substance to the rule of law - the pivotal moment in the theory - Dyzenhaus' analysis is brief and contains little more than a recitation of broad generalities. ${ }^{55}$ The most developed elaboration of his 'common law constitution of legality'56 is contained in this passage:

In summary, my position is that legislation must be capable of being interpreted in such a way that it can be enforced in accordance with the requirements of due process; the officials who implement it can comply with a duty to act fairly, reasonably and in a fashion that respects the equality of all those who are subject to the law and independent judges are entitled to review the decisions of these officials to check that they do so comply. I will also argue that our understanding of concepts such as fairness, reasonableness, and equality is inevitably influenced by our evolving view of the individual who is subject to the law, the legal subject in short, and thus in recent times by the claim that the legal subject has to be regarded primarily as the bearer of human rights. ${ }^{57}$

But this short catalogue gives little indication of how these general values are supposed to play out in the world of political and legal practice. It tells us nothing about where the chosen values come from, save that they are inherent to the very

inappropriate for judicial consideration. (T.R.S. Allan, 'Human Rights and Judicial Review: A Critique of Due Deference' (2006) 65 CLJ 671, 675 \& 682.)

54 The best example of this in the current climate is the decision of Lord Hoffmann in $A \mathrm{v}$ Secretary of State for the Home Department [2004] UKHL 56. For analysis see T. Poole, 'Harnessing the Power of the Past? Lord Hoffmann and the Belmarsh Detainees Case' (2005) 32 JLS 534.

55 This is an exact echo, incidentally, of the flaw that besets various attempts by common law theorists to articulate the supposedly basic, 'timeless' values of the common law in their general theoretical work: see further T. Poole, 'Questioning Common Law Constitutionalism’ (2005) 25 Legal Studies 142.

${ }^{56}$ Dyzenhaus, Constitution of Law, n 4 above, 87.

57 ibid, 12-3. 
notion of legality which, given that this is precisely the subject in dispute, rather begs the question. The values alluded to - 'due process' and the duty to act fairly and reasonably; equality, fairness and reasonableness - are certainly not meaningless; but nor do they offer a coherent blueprint for judicial (or any other) decision-making. The reference to 'human rights' does little to remedy this deficiency. True, the instantiation of human rights in a legal order can certainly alter the perspective from which judges and other decision-makers approach problems. But anyone familiar with the interpretation of human rights instruments is aware of how open-textured such instruments are. ${ }^{58}$ This indeterminacy is particularly acute in emergency contexts. Many human rights instruments contain provisions allowing for derogation from human rights obligations in emergency or crisis situations, and the practice of courts in policing their exercise has been anything but consistent. Gross and Ní Aoláin, for instance, refer to the record of the European Court of Human Rights on this score as a 'cocktail of robustness and timidity. 59

Moreover, we are not told why these particular values should outweigh (always? generally?) other, countervailing values, such as 'security' or even national self-preservation. And even if they are to act as 'trumps', the concepts are elastic and malleable enough to allow for an almost infinite range of interpretive options, particularly in situations of putative crisis. As Vermeule writes, administrative law is "built around a series of open-ended standards or adjustable parameters - for example what counts as "arbitrary" or "unreasonable", whether evidence is "substantial", whether a statute is or is not "clear" - that courts can and do adjust during perceived emergencies to increase deference to administrative agencies. ${ }^{60}$ Nor does the incantation of certain values explain why judges in the conditions of uncertainty, secrecy and half-knowledge that beset decision-making in this context ${ }^{61}$ should take a central role in the review of the exercise of emergency (or similar) powers. 'Carl Schmitt's challenge'62 receives, then, no convincing response. We are left instead with an impassioned plea for more 'believers in the rule of law', without whom 'law cannot deliver its resources to us.' ${ }^{63}$

Dyzenhaus' theory of the emergency constitution suffers from the same defects as theories of common law constitutionalism more generally. To the uninitiated, common law constitutionalism often appears like an exercise in wish-

\footnotetext{
${ }^{58}$ For a critical exploration of the decision-making of the European Court of Human Rights see M.-B. Dembour, Who Believes in Human Rights? (Cambridge: Cambridge University Press, 2006).

59 O. Gross and F. Ní Aoláin, Law in Times of Crisis (Cambridge: Cambridge University Press, 2006) 272.

${ }^{60}$ A. Vermeule, 'Our Schmittian Administrative Law' (2009) Harvard Law Review (forthcoming).

${ }^{61}$ Dyzenhaus does recognize the difficulties inherent in the situation. Referring to Simpson's sceptical assessment of the capacity of the court in this context, he says that 'Given the secrecy and duplicity of the secret services and the judicial inability to go beyond their claims about the need to protect their information from scrutiny, the kinds of reason that will be offered, and with which judges will have to contend themselves, will not allow for any genuine testing of the validity of the administrative decisions.' (Constitution of Law, n 4 above, 26.) See also D. Dyzenhaus, 'Deference, Security and Human Rights' in Goold and Lazarus, Security and Human Rights, n 19 above.

${ }^{62}$ Constitution of Law, n 4 above, 39: 'Schmitt's claim is ... [that the] space beyond law is not so much produced by law as revealed when the mask of liberal legality is stripped away by the political.'

63 ibid, 64.
} 
fulfilment. We are drawn to the idea that there are some deep, transcendental values in the common law, which might operate as 'apolitical political principles'64 against which we might measure governmental action; but when we look for them, we don't quite know where to find them. And the values we do seem to find are either lacking in specificity and so incapable of acting as true guiding principles, or else have little or no historical pedigree and so conflict with the core idea that the values in question are embedded in a common law framework which has evolved over the course of social and political development and so reflect deep-rooted community mores. The 'historical' dimensions of the theory tend to be as flawed as the 'political' ones. Those common law constitutionalists who do delve into the past do so selectively and unsystematically, typically attempting a (very partial) 'reconstruction' of a supposed golden age - usually the era of Coke - in which courts acted like Hayekian guardians of the constitutional order, defending rights and checking governmental abuses of power without fear or favour. Needless to say, this account of constitutional 'development' (English or otherwise) is anachronistic and unsupported by any serious modern historian. ${ }^{65}$

The reason why Dyzenhaus and the other common law constitutionalists fail to articulate values 'fundamental', in the double sense of 'basic' and 'historical', lies in their misunderstanding of the nature of the common law. ${ }^{66} \mathrm{We}$ may certainly allow that the common law, particularly but not solely ${ }^{67}$ in its more recent manifestations, is partly a collection of principles. But it is a far more complex phenomenon than this simple Dworkinian reworking would allow. ${ }^{68}$ The common law is a matrix comprising rules, maxims, principles, traditions, processes and professional practices. ${ }^{69}$ Indeed, processes and practices would have been the defining characteristic of common law at least into the early modern period. 'The history of the common law', Glenn writes, is dominated by questions of jurisdiction, writs, and remedies. ${ }^{3} 70$ The common law was not identified in terms of its content. This is why Postema defined the common law not as a system of positive rules but as a practised framework of practical reasoning. ${ }^{71}$ The common law also seems to inculcate in those who work and study within it a certain mentalité or habit

\footnotetext{
64 See, e.g., Sir J. Laws, 'The Constitution: Morals and Rights' [1996] PL 622, 628: courts are under and obligation 'to protect values which no democratic politician could honestly contest: values which, therefore, can best be described as apolitical, since they stand together above the rancorous but vital dissensions of party politicians.'

${ }^{65}$ For a comprehensive critique of the common law constitutionalists' argument from history see Tomkins, n 14 above, ch 3 .

${ }^{66}$ It may be possible to argue that the common law, as it now stands, is different from how it used to be, both in terms of standards and make-up. But this argument is not the one common law constitutionalists make. Nor does it fit the self-understanding of participants within the system.

${ }^{67}$ See, e.g., D. Lieberman, The Province of Legislation Determined: Legal Theory in Eighteenth-Century Britain (Cambrige: Cambrige University Press, 1989).

${ }^{68}$ For the connection between common law constitutionalism and Dworkinian method see T.R.S. Allan, 'Dworkin and Dicey: The Rule of Law as Integrity' (1988) 8 OJLS 266.

${ }^{69}$ See, e.g., J.H. Baker, 'Why the History of English Law has not been Finished' (2000) 59 CLJ 62.

${ }^{70}$ H. Patrick Glenn, On Common Laws (Oxford: Oxford University Press, 2005) 29.

${ }^{71}$ G. Postema, 'Philosophy of the Common Law' in J. Coleman and S. Shapiro (eds), The Oxford Handbook of Jurisprudence and Philosophy of Law (Oxford: Oxford University Press, 2002) 596.
} 
of mind which, while not static, does show quite strikingly similar qualities across otherwise very different eras..$^{72}$ (It would still be a stretch, even so, to recast Coke as a Dworkinian liberal, although this has not stopped people from trying. ${ }^{73}$ ) The multi-dimensional nature of common law, certainly when combined with its immense longevity, should be enough to warn against attempts to understand its history in Whiggish terms as the story of legal principles 'working themselves pure', although this indeed may be one narrative strand within a much more complex story. And this is even before we start thinking, as we should given the various odysseys that the common law has embarked on in the modern period, in terms of a plurality of common laws rather than one common law. ${ }^{74}$

Let us focus for a moment on those common law characteristics of longevity and pluralism. It is difficult to imagine any institution carrying 'hard-edged' normative principles of the type claimed by Allan and Dyzenhaus to have managed anything like the actual trajectory of the common law. Rather like a welldesigned bridge, the common law's various journeys, both historical and geographical, ${ }^{75}$ have been possible because, while retaining its own recognisable shape and structure, it has been flexible enough, particularly but not solely in normative terms, to adapt to (sometimes fundamental) changes in the social and political weather. It is the capaciousness of common law, its normative 'give', that is paradigmatic and not the solid core of relatively unchanged normativity that the common law constitutionalists imagine. The constitution, Allison argues in a recent book, 'is lacking in systemic elaboration and limited in express normativity. ${ }^{76}$ The history of the common law in the constitutional sphere pivots around the dynamics of change and continuity. It has been able to respond to and accommodate enormously varied patterns of social and political ordering although it almost always seeks to do so under the guise of continuity. But this veneer of rhetoric - the classic modern example being Lord Bridge's judgment in Factortame (No. 2) ${ }^{77}$ - should not obscure the fact that it is relatively easy to accommodate within its interstices really quite substantial change.

This is not to say that the common law, at any given moment, is devoid of real normative content, but rather that such normative content tends, in the

\footnotetext{
72 See, e.g., D. Sugarman, 'Legal Theory, the Common Law Mind and the Making of the Textbook Tradition' in W. Twining (ed.), Legal Theory and Common Law (Oxford: Blackwell, 1986); J.W. Tubbs, The Common Law Mind: Medieval and Early Modern Conceptions (London: John Hopkins University Press, 2000), ch 7.

73 Mauro Cappelletti claims Coke as the champion of the common law as a higher law in the era of natural justice: 'The Significance of Judicial Review of Legislation in the Contemporary World' in E. von Caemmerer, S. Mentschikoff and K. Zweigert (eds), Ius Privatum Gentium: Festschrift für Max Rheinstein (Tubingen: Mohr, vol. 1, 1969) 147-64. See also E.S. Corwin, "The "Higher Law" Background of American Constitutional Law' (1928) 42 Harvard LR 367.

${ }^{74} \mathrm{n} 70$ above, 42: 'The common laws of Europe thus existed in great variety. Ius commune did not exist in singular but in multiple form, as iura communia, and there was vigorous relations not only between the common laws and the particular laws of each of them, but also between the common laws themselves.'

75 See, e.g., D. Neal, The Rule of Law in a Penal Colony: Law and Power in New South Wales (Cambrige: Cambrige University Press, 1991).

${ }^{76}$ J.W.F. Allison, The English Historical Constitution (Cambridge: Cambridge University Press, 2007) 128.

77 R v Secretary of State for Transport, exp Factortame Ltd (No. 2) [1991] 1 AC 603 at 659D.
} 
constitutional sphere at least, to be reasonably 'soft-edged' - whether or not it appears as such - and reasonably susceptible to change. It is probably no coincidence that the 'harder' rules of common law - at least in the public law context - tend to be procedural rather than substantive. (For instance, the rule much lauded by common law constitutionalists - that the common law will presume that Parliament did not intend to legislate illiberally absent evidence of an explicit legislative intention to the contrary. ${ }^{78}$ ) Coke's flirtation with the idea of imposing substantive controls on Parliament in the name of the (artificial?) reason of the common law - if that indeed is what he sought to $\mathrm{do}^{79}$ - should be seen rather as an outlier within this tradition. ${ }^{80}$ As Allison argues, it is economy that characterises the common law tradition, at least in the public law context. Economy, which takes a variety of forms, stems from 'judicial pragmatism, a reluctance to risk political controversy, understandings of the rough English separation of powers and the sparing deployment or engagement of judicial resources. ${ }^{81}$ The harder-edged rules of common law that do seem to have thrived for long periods - the classic public law example being the principle of parliamentary sovereignty, but we might also think of the importance attached to contract and (above all) property ${ }^{82}$ - generally owe their status to the importance of these ideas as a matter of political and social history. ${ }^{83}$ Once social and political conditions change - as the recent cases on parliamentary sovereignty perhaps indicate ${ }^{84}$ - rules that seemed previously fixed begin to crumble (or, more commonly, modify) quite rapidly.

There are two main points that arise from this analysis. It is hard to see, first of all, how the common law thesis relating to emergency powers can be maintained by Dyzenhaus \& Co.. If the common law - inasmuch as it is a body of principles - is more often than not soft-edged and procedural rather than hardedged and substantive, cognitively open and pragmatic rather than resolutely or defiantly normative, then the notion that a value-laden rule of law derived from common law sources can determine what counts as exceptional (and ipso facto invalid) appears unsustainable. The cognitive openness of common law makes it

\footnotetext{
${ }^{78}$ See, e.g., $R$ v Secretary of State for Social Security, ex p Joint Council for the Welfare of Immigrants [1997] 1 WLR 275 (overturning the government's regulations depriving certain categories of asylum seeker of welfare payments).

${ }_{79}$ See, e.g., C. Hill, 'Sir Edward Coke - myth-maker' in C. Hill, Intellectual Origins of the English Revolution (Oxford: Clarendon Press, 1972); n 76 above, ch 6.

${ }^{80}$ See J. Goldsworthy, The Sovereignty of Parliament: History and Philosophy (Oxford: Clarendon Press, 1999).

$81 \mathrm{n} 76$ above, 125-6. The forms of economy identified by Allison are as follows: (i) the imposition of procedural controls, which leave the decision-maker free to decide on substance; (ii) the minimisation of change and, where change is necessary, the appearance of change; (iii) the avoidance of contentious abstractions of principle; (iv) statutory construction through the formalistic coupling of a judicial decision to the intention of Parliament; (v) 'a general obfuscation, through a failure to explain or acknowledge all the issues at stake and thus not clearly or specifically to address them'.

${ }^{82}$ See, e.g., D. J. Seipp, 'The Concept of Property in the Early Common Law' (1994) 12 Law and History Review 29.

83 See, e.g., Sir W. Wade, 'The Basis of Legal Sovereignty' (1955) CLJ 172.

${ }^{84}$ Factortame (No. 2), n 77 above; $R$ v Secretary of State for Employment, ex p Equal Opportunities Commission [1995] 1 AC 1; Thoburn v Sunderland City Council [2003] QB 151; [2002] EWHC 195; Jackson v AttorneyGeneral [2005] UKHL 56; [2006] AC 262.
} 
difficult to determine with sufficient precision what counts as 'normal' in a certain situation. Consider, for instance, how the British courts recently struggled with a question relating to the admissibility of evidence that may have been obtained by torture overseas. One might have thought that torture being what Waldron calls a 'legal archetype' or hallmark - a provision emblematic of a legal system's larger commitment to nonbrutality ${ }^{85}$ - that this would have been a straightforward case. But the Court of Appeal and House of Lords came to opposite conclusions, and even though the House of Lords started from a principled position similar to that advocated by Waldron, the majority and minority applied that principle in very different ways. ${ }^{86}$ Second, even if we could determine the 'normal' in this way, the capaciousness of the common law - the fact that there is not much that is hardwired' into it in terms of strong constitutional norms - means that there is often no strong basis on which to determine whether the exceptional is necessarily illegitimate, as what is 'normal' to the common law is in any case prone to change.

\section{PART III: THE ILLUSIONS OF (EXTRA-)LEGALITY?}

Part I began with Locke's framework for the emergency powers, and argued that a distinction based on a formal distinction between 'normal' and 'emergency' powers - or, more precisely, prerogative and legislation - is no longer operable given the conditions of modern government. Part II questioned the idea advanced by Dyzenhaus and others that the values of legality embedded in the common law might offer a basis for determining the 'normal'. Widening the lens, we might say that both formal (Lockean) and substantive (common law) solutions represent two different ways of responding to arguments about extra-constitutionality. The first solution accepts the existence (and necessity) of an extra-constitutional realm, but tries to 'confine' it to the world of the prerogative. The second tries (not always convincingly) to deny the need for extra-constitutionality, and seeks to bring extraconstitutional moves into the constitutional fold - Dyzenhaus draws on a particular idea of the common law in order to effect this. In this final section, I extend the argument by suggesting that the dynamic nature of constitutions and constitutionalism makes it hard to determine with any degree of precision what ought to count as 'constitutional' and 'unconstitutional', 'normal' and 'exceptional'. To help me make this point, I examine the most stridently dichotomous (and

\footnotetext{
85 J. Waldron, 'Torture and Positive Law: Jurisprudence for the White House' (2005) 105 Columbia Law Review 1681.

${ }^{86}$ For analysis see S. Shah, 'The UK's Anti-Terror Legislation and the House of Lords: The Battle Continues' (2006) 6 Human Rights Law Review 416.
} 
therefore most static) model of the emergency constitution currently in circulation: the 'extra-legal measures model' identified and occasionally advocated by Gross. ${ }^{87}$

The 'extra-legal measures model' accepts, with Locke, that exceptional responses may sometimes be necessary to deal with crises, but insists that the natural tendency in such circumstances for courts and legislatures to accommodate executive demands - and thereby water down 'normal' standards and constitutional protections - should be fought by requiring the executive to act openly outside the normal legal order. 'Hard cases make bad law. Times of emergency make some of the hardest of cases. What the Extra-Legal Measures model attempts to do is keep the ordinary legal system clean and distinct from the dirty and messy reality of emergency so as to prevent, or at least minimize, the perversion of that system in search for answers to hard, exceptional cases.' ${ }^{\prime 8}$ Note, however, that the 'extra-legal' realm portrayed here is rather different from the world of the Lockean prerogative, which was a power entirely extra et contra legem. The extra-legal measures model devises a number of legal (and other) checks, mostly ex post, on exercises of extra-legal powers. It seeks to impose, in other words, particular types of constitutional restrictions on what is supposedly an extra-constitutional realm. The 'extra-constitutional' world that we are being presented with is not, then, a straightforwardly exceptional category but amounts rather to a 'lower order' of constitutionality.

The extra-legal measures model stands or falls by the suitability of its basic binary structure, according to which 'normal' cedes in certain conditions to 'exceptional' (or perhaps more accurately 'sub-normal') which cedes in turn (one hopes) back to 'normal'. This structure echoes the understanding of the institution of dictatorship in the Roman Republic, which provides the main inspiration behind Gross' model. ${ }^{89}$ But I am sceptical about the viability of this model in current conditions, particularly British conditions. While Gross is aware of the danger of what he calls, in Schmittian brogue, the 'normalisation of the exception', 90 it is not clear how his solution manages to avoid them. The extralegal measures model's binary structure sits uncomfortably with current practice which, as we saw in Part I, tends towards the sublimation of emergency powers within normal law-making processes - the move from using prerogative powers to ordinary legislation to respond to crises. Beyond this, it is hard to see how the extra-legal measures model might work in a political community which lacks determinative legal/constitutional content. The types of distinctions upon which the model relies are simply not available, I would suggest, in a fluid and openended constitutional structure of the type that prevails in the UK. In such an

87 O. Gross, 'Chaos and Rules: Should Responses to Violent Crises Always be Constitutional?' (2003) 112 Yale LJ 1011. See also Tushnet, n 3 above.

88 n 59 above, 161.

${ }^{89}$ See, e.g., A. Lintott, The Constitution of the Roman Republic (Oxford: Oxford University Press, 1999) 109-

115; Agamben, State of Exception, n 2 above, ch. 3.

${ }^{90}$ See, e.g., O. Gross, 'What “Emergency” Regime?' (2006) 13 Constellations 74. 
environment, how is the 'normal' (or for that matter the 'exceptional') meant to have determinative shape?

More fundamentally, I am not convinced about the static picture of constitutionalism that underpins the binary structure of the extra-legal measures model and which serves to obscure the dimensions of dynamism and change that are as much a part of constitutional order as continuity. The exceptional in the extra-legal measures model operates almost like a caesura in constitutional time. The model presumes, in other words, a (static) body of 'normal' law being set aside for a time and then brought back in pristine form after the emergency is over. (That, after all, is the reason why it is favoured by its advocates.) I want to focus first on the end of this process, being turning to its beginning. The idea that legal practice might revert to the status quo ante untainted by what had happened during the crisis, on the legal plane or the social or political, is implausible. Bracketing objections ${ }^{91}$ concerning the 'Pontius Pilate role' that the model accords courts (and other institutions?) in times of crisis - washing their hands so as facilitate others getting them dirty - it misunderstands human development. Attempts to recapture the past, while rhetorically common in politics, almost never produce true reversions. (This applies, strangely enough, to the formation of the common law. At least on one account, Henry II 'created' the common law system while attempting - honestly it would seem - to revert to an older system of justice. ${ }^{92}$ ) More comprehensive reversion tends to operate more like the 'recapitulation' section in a sonata form movement: earlier themes reappear but usually infused with ideas from the intervening 'development' section; and even if they do reappear in untainted form, they tend to sound different in light of what went on in the development.

But what about the beginning of the process - the status quo of the status quo ante? As well as downplaying the difficulties, at least in modern political conditions, of determining an 'exceptional' situation, the extra-legal measures model also tends to overplay the normalcy of the normal. It rests, that is, on a static account of constitutions which largely ignores the capacity inherent to constitutions to be reworked and reformed. As the previous analysis of the common law constitution indicates if it doesn't show, constitutions are more fluid in practice than this model suggests. ${ }^{93}$ But, in exaggerating the normal nature of the normal, the model also exaggerates the exceptional nature of the exceptional. There is often a political move at the heart of this. The discourse of exceptionalism, in supporting an illusory image of the timelessness and changelessness of constitutions, lends itself

${ }^{91}$ See, e.g., C. Gearty, 'The Superpatriotic Fervour of the Moment' (2008) 28 Oxford Journal of Legal Studies 183.

${ }^{2}$ See, e.g., S.F.C. Milsom, Historical Foundations of the Common Law (London: Butterworths, 2nd ed, 1981); R.C. van Caenegem, The Birth of the English Common Law (Cambridge: Cambridge University Press, 2nd ed, 1988); Cf P. Wormald, The Making of English Law: King Alfred to the Twelfth Century, vol. 1: Legislation and its Limits (Oxford: Blackwell, 1999).

${ }^{93}$ Lest this be thought to be a phenomenon peculiar to the common law constitution, see Bruce Ackerman's grand narrative of constitutional change in the United States: We The People, Volume 2: Transformations (London: Harvard University Press, 1998). 
to the criticism of certain developments. Are we talking, then, about a discourse whose main end is the propping up a status quo which the discussant takes to be good? Perhaps there is nothing wrong (or exceptional) in this. But it is not altogether clear that we as constitutional scholars ought to deny the complexity of our discipline, its susceptibility to change, perhaps even its sheer 'fuzziness', so that we can contribute more readily to political campaigns. 